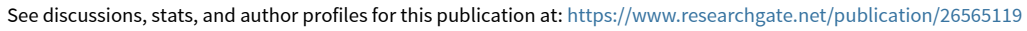

\title{
Greater Understanding of How Soybean has the Ability to Produce Similar Yields Across a Broad Range of Plant Populations
}

Article in Pakistan Journal of Biological Sciences · September 2005

DOI: 10.3923/pjbs.2005.1200.1202 S Source: DOAJ

CITATIONS

0

2 authors:

Ahad Madani

Islamic Azad University of Gonabad

23 PUBLICATIONS 229 CITATIONS

SEE PROFILE
READS

20

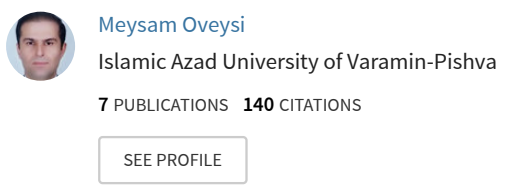

Some of the authors of this publication are also working on these related projects:

Response of cotton to irrigation, fertilization and plant density in a semi-arid region of Iran View project 
Pakistan Journal of Biological Sciences 8 (9): 1200-1202, 2005

ISSN 1028-8880

(C) 2005 Asian Network for Scientific Information

\title{
Greater Understanding of How Soybean has the Ability to Produce Similar Yields Across a Broad Range of Plant Populations
}

\author{
Madani Ahad and Oveysi Meysam \\ Department of Agronomy, Agriculture College of Tehran University, Karaj, Iran
}

\begin{abstract}
The objectives of present study were to increase understanding of how NAR and LAI contribute to CGR and grain yield equilibration across plant populations. Maximum and minimum grain yields of 433.2 and $262.9 \mathrm{~g} \mathrm{~m}^{-2}$ were attained by 100 and 20 plants $\mathrm{m}^{-2}$, respectively. However, no grain yield significant differences were obtained among 60,80 and 100 plants $\mathrm{m}^{-2}$. Greater leaf expansion rate during emergence to early flowering $\left(\mathrm{R}_{1}\right)$ and greater light interception per unit LAI during early flowering to early seed filling $\left(\mathrm{R}_{1}\right.$ to $\left.\mathrm{R}_{5}\right)$ for low vs. high plant population caused to equal LAI at $\mathrm{R}_{1}$ and equal NAR during early reproductive among 60,80 and 100 plant populations, resulting CGR equilibration during early reproductive and similar pod per plant and grain yield between these plant populations.
\end{abstract}

Key words: Plant population, yield, leaf expansion rate, light interception

\section{INTRODUCTION}

Understanding of how growth dynamic factors across a broad range of management systems results in similar yield will aid identifying genetic and agronomic strategies for attain and maintain adequate photosynthesis capacity ${ }^{[1]}$. Similar yield across plant populations results from equilibration of CGR by early reproductive period, which causes an equivalent number of pods per square meter ${ }^{[2]}$. The early reproductive period is the most sensitive to altered source strength and CGR since it is the time in which the final pod numbers are formed ${ }^{[3]}$. CGR equilibration occurs through adjustments of LAI and NAR ${ }^{[4,5]}$. Greater NAR in low compared with normal plant populations during the late vegetative and early reproductive periods is sometimes contributing factor to CGR equilibration ${ }^{[6]}$. Greater light interception per unit LAI was associated with this NAR advantage for low plant populations ${ }^{[7]}$. Leaf area expansion rate has been reported to be greater in spare vs. tense populations, suggesting that more rapid LAI development per unit LAI may contribute to CGR equilibration across plant populations ${ }^{[8]}$. Since most LAI development during the early reproductive stage occurs on branches ${ }^{[9]}$, greater partitioning of total dry matter into lateral branches by low plant population could result in relatively faster LAI expansion. This occurs because of greater interplant reflection of far red light within dense stands. Boqest ${ }^{[4]}$ demonstrated under field conditions that an increased ratio of red/far red light ratio resulted in greater branch development in soybean. The objectives of present study were to increase understanding of how NAR and LAI contribute to CGR and grain yield equilibration across plant populations.

\section{MATERIALS AND METHODS}

The experiment was carried out at the Agriculture Research Farm of Agronomy Management Organization of Isfahan, Iran during 2003 . The site is located at $35^{\circ} 25^{\circ}$ $\mathrm{N}$ latitude, $71^{\circ} 25^{\prime} \mathrm{E}$ longitudes and an altitude of $1673 \mathrm{~m}$ above sea level. Golpayegan is located about $130 \mathrm{~km}$ of Isfahan thus has a semi-arid ( $375 \mathrm{~mm}$ rainfall yearly) climate. The soil of experimental site was clay loam with a clay type of montmorillionite, low in nitrogen $(0.04-0.05 \%)$, low in organic matter $(0.9-1 \%)$ and alkaline in reaction with a pH of 7.8 and $\mathrm{Ec}=0.44 \mathrm{dS} \mathrm{m}^{-1}$.

The experiment was laid out in Randomized Complete Block Design have four replication with five plant populations $\left(20,40,60,80,100\right.$ plant $\left.\mathrm{m}^{-2}\right)$. A sub plot size of $3 \times 6 \mathrm{~m}$, having 6 rows $6 \mathrm{~m}$ long was used. Sowing was done in hills. Two to five seeds per hill were planted and thinning was done to corresponding to $20,40,60,80$ and 100 plants $\mathrm{m}^{-2}$. Normal cultural practice was followed uniformly for all experimental units. The plots were hand weeded in different Vegetative stages. Irrigation was applied at weekly interval.

Areas of $4 \mathrm{~m}^{2}$ ( $2 \mathrm{~m}$ from 4 middle rows) were hand harvested from each sub plot to estimate grain yield. Sections of $1 \mathrm{~m}^{2}(0.5 \mathrm{~m}$ from 4 middle rows) from each plot were hand harvested at early flowering $\left(R_{1}\right)$, early seed filling period $\left(R_{5}\right)$ to determine leaf area, leaf dry weight

Corresponding Author: Madani Ahad, Department of Agronomy, Agriculture College of Tehran University, Karaj, Iran 
and Total Dry Matter (TDM) and TDM partitioning into branches at early flowering $\left(\mathrm{R}_{1}\right)$. Dry weight samples were oven-dried at $60^{\circ} \mathrm{C}$ to a constant weight to determine growth on a dry weight basis. Leaf area index was measured at early flowering $\left(\mathrm{R}_{1}\right)$ and early seed filling period $\left(\mathrm{R}_{5}\right)$ with a leaf area meter. Crop GrowthRate (CGR) and Net Assimilation Rate (NAR) during early reproductive period (early flowering to early seed filling period were calculated by following equations:

$$
\begin{aligned}
& \text { CGR }=\left(\mathrm{W}_{2}-\mathrm{W}_{1}\right) /\left(\mathrm{T}_{2}-\mathrm{T}_{1}\right)(1 / \mathrm{S}) \\
& \text { NAR }=\left(\mathrm{W}_{2}-\mathrm{W}_{1}\right) /\left(\mathrm{T}_{2}-\mathrm{T}_{1}\right)\left(\ln \mathrm{A}_{2}-\ln \mathrm{A}_{1}\right) /\left(\mathrm{A}_{2}-\mathrm{A}_{1}\right)
\end{aligned}
$$

Where,

$\mathrm{S} \quad=$ The ground area on which the dry weights have been estimated $\left(\mathrm{m}^{2}\right)$

$\mathrm{T}_{2}-\mathrm{T}_{1}=$ Time interval early flowering to early seed filling stages (Day for CGR, Week for NAR)

$\mathrm{W}_{2}-\mathrm{W}_{1}=$ Total dry matter difference between early flowering to early seed filling stages (gr)

$\mathrm{A}_{2}-\mathrm{A}_{1}=$ Leaf area difference between early flowering to early seed filling stages $\left(\mathrm{m}^{2}\right)$.

$\mathrm{K}$ value [(under canopy radiation/top canopy radiation) $\times 100$ ] measured using a sun scan instrument in soil surface of under canopy at early flowering.

Data were statistically analysed using analysis of variance technique appropriate for Randomize Complete Block Design. Duncan $(\mathrm{p}<0.05)$ test was employed for mean separation when $\mathrm{F}$-values were significant.

\section{RESULTS AND DISCUSSION}

The statistical analysis of data indicates that plant populations had significant effect on LAI at early flowering (Table 1). LAI increased $40.5 \%$ with increase in plant density from 20 to 100 plants $\mathrm{m}^{-2}$ and maximum LAI of 4.81 was recorded at 100 plants $\mathrm{m}^{-2}$ (Table 1). How ever, no LAI significant differences were observed among 60,80 and 100 plants $\mathrm{m}^{-2}$ (Table 1 ). Loomis ${ }^{[9]}$ reported that soybean yield continued to increase until the population reached 55 plants $\mathrm{m}^{-2}$, the population in which an LAI of 4 was reached by full pod $\left(\mathrm{R}_{4}\right)$. Jiang and $\mathrm{Egli}^{[10]}$ demonstrated that if LAI was above $5,20 \%$ of the leaf area could be removed without a yield decline.

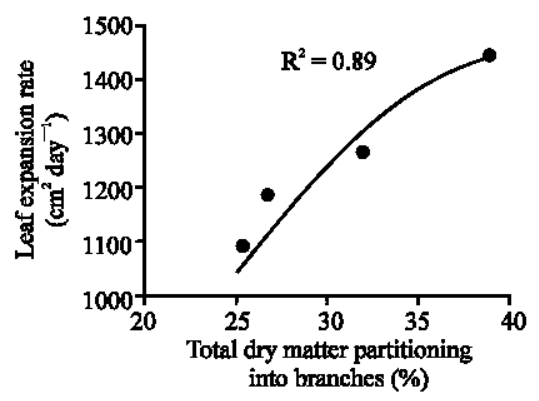

Fig. 1: Relationship between leaf expansion rate and total dry matter partitioning into branches

This LAI equilibration at $R_{1}$ is because of significantly greater leaf expansion rate during emergence to early flowering for low vs. high plant population (Table 1).

TDM partitioning to lateral branches at $R_{1}$ was significantly greater for low vs. high plant populations (Table 1). Greater partitioning of total dry matter into lateral branches by low plant population could result in relatively faster LAI expansion (Fig. 1)

The statistical analysis of data indicates that plant populations had significant effect on NAR during early reproductive period (Table 1 ). NAR decreased $20.2 \%$ with increase in plant density from 20 to 100 plants $\mathrm{m}^{-2}$ and maximum NAR of $6.03 \mathrm{~g} \mathrm{~m}^{-2}$ week $^{-1}$ was recorded at 20 plants $\mathrm{m}^{-2}$ (Table 1). How ever, no NAR significant differences were observed among 60,80 and 100 plants $\mathrm{m}^{-2}$ (Table 1 ). This NAR equilibration during $\mathrm{R}_{1}$ to $R_{5}$ is because of significantly greater light interception per unit LAI. It may due to significantly greater under canopy radiation for low vs. high plant population (Fig. 2). Crop growth rate equilibration across 60,80 and 100 plants $\mathrm{m}^{-2}$ occurred through adjustments of NAR and LAI (Table 1).

A significant positive relation ship (Fig. 3) between pod $\mathrm{m}^{-2}$ and CGR during $\mathrm{R}_{1}$ to $\mathrm{R}_{5}$, indicating that greater CGR during early reproductive stage cause to greater number of pods per square meter yield. In other hand, crop growth rate equilibration across 60,80 and 100 plants $\mathrm{m}^{-2}$ occurred through adjustments of NAR and LAI, resulting equivalent pod $\mathrm{m}^{-2}$ and similar yield of these populations. Sinclair ${ }^{[2]}$ reported that soybean

\begin{tabular}{|c|c|c|c|c|c|c|c|c|}
\hline $\begin{array}{l}\text { Plant } \\
\text { populations } \\
\text { (plants } \mathrm{m}^{-2} \text { ) }\end{array}$ & $\begin{array}{l}\text { Grain yield } \\
\left(\mathrm{g} \mathrm{m}^{-2}\right)\end{array}$ & $\begin{array}{l}\text { LER during } \\
\text { emergence to } \\
\mathrm{R}_{1}\left(\mathrm{~cm}^{-2} \text { day }^{-1}\right)\end{array}$ & $\begin{array}{l}\text { LAI } \\
\text { at } R_{1}\end{array}$ & $\begin{array}{l}\text { Under canopy } \\
\text { radiation }(\%)\end{array}$ & $\begin{array}{l}\text { NAR during } \\
\mathrm{R}_{1} \text { to } \mathrm{R}_{5} \\
\left(\mathrm{~g} \mathrm{~m}^{-2} \text { week }^{-1}\right)\end{array}$ & $\begin{array}{l}\text { CGR during } \\
\mathrm{R}_{1} \text { to } \mathrm{R}_{5} \\
\left(\mathrm{~g} \mathrm{~m}^{-2} \mathrm{day}^{-1}\right)\end{array}$ & $\begin{array}{l}\text { TDM partitioning } \\
\text { to lateral branches } \\
\text { at R1 }(\%)\end{array}$ & Pod m ${ }^{-2}$ \\
\hline 20 & $278.6 \mathrm{c}$ & $1443 a$ & $2.86 \mathrm{c}$ & $39.1 \mathrm{a}$ & $6.03 a$ & $2.46 \mathrm{c}$ & $38.76 \mathrm{a}$ & $3600 \mathrm{c}$ \\
\hline 40 & $365.5 b$ & $1265 \mathrm{~b}$ & $3.64 \mathrm{~b}$ & $35.3 b$ & $5.79 \mathrm{~b}$ & $3.01 \mathrm{~b}$ & $31.88 \mathrm{~b}$ & $4010 \mathrm{~b}$ \\
\hline 60 & $415.6 \mathrm{a}$ & $1185 \mathrm{c}$ & $4.55 \mathrm{a}$ & $32.9 \mathrm{c}$ & $4.95 \mathrm{c}$ & $3.21 \mathrm{a}$ & $26.64 c$ & $4952 a$ \\
\hline 80 & $420.7 \mathrm{a}$ & $1092 \mathrm{c}$ & $4.62 \mathrm{a}$ & $31.7 \mathrm{c}$ & $4.89 \mathrm{c}$ & $3.22 \mathrm{a}$ & $25.33 \mathrm{c}$ & $5054 a$ \\
\hline 100 & $442.3 \mathrm{a}$ & $962 d$ & $4.81 \mathrm{a}$ & $30.1 \mathrm{c}$ & $4.82 \mathrm{c}$ & $3.31 \mathrm{a}$ & $25.02 \mathrm{c}$ & $5211 \mathrm{a}$ \\
\hline
\end{tabular}

Table 1: Mean comparison of some traits as affected by plant populations

LER: leaf area expansion; $\mathrm{R}_{1}$ : early flowering; LAI: leaf area index; NAR: net assimilation rate; $\mathrm{R}_{5}$ : early seed filling; TDM: total dry matter

*Means of the same category followed by different letters are significantly different at $0.05 \%$ level of probability using Duncan test. 


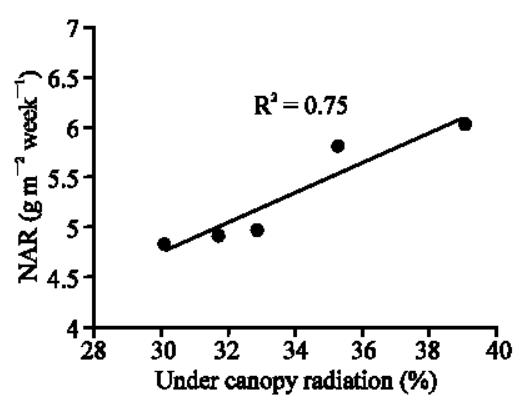

Fig. 2: Relationship between under canopy radiation and NAR

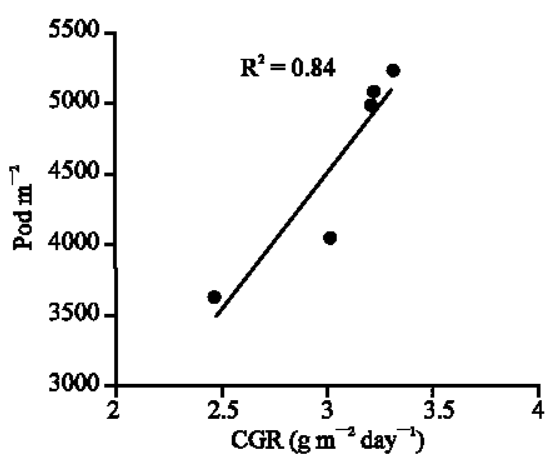

Fig. 3: Relationship between CGR during early reproduction stage and pod per square meter

yield continued to increase until the population reached 55 plants $\mathrm{m}^{-2}$, the population in which an LAI of 4 was reached by full pod $\left(\mathrm{R}_{4}\right)$.

\section{REFERENCES}

1. Kasperbauer, J.E. and B.G. Harville, 1994. A criterion for acceptance of narrow-row culture in soybean. Agron. J., 86: 1103-1106.
2. Sinclair, T.R. and T. Horie, 1989. Leaf nitrogen, photosynthesis and crop radiation use efficiency: A review. Crop Sci., 29: 90-98.

3. Wells, R., 1993. Dynamics of soybean growth in variable planting patterns. Agron. J., 85: 44-48.

4. Boquet, D.J. and D.M. Walker, 1998. Seeding rates for soybeans in various planting patterns. Louisiana Agric., 23: 22-23.

5. Carpenter, A.C. and J.E. Board, 2000. Branch yield components controlling soybean yield stability across plant populations. Crop Sci., 37: 885-891.

6. Sanchez, R.A., J.J. Casal, C.L. Ballare and A.L. Scopel, 1997. Plant Response to Canopy Density Mediated by Photomorphogenic Processes. In: Buxton, D.R. et al., (Ed.), Inter Crop Sci. CSSA, Madison, WI., pp: 779-788

7. Carpenter, A.C. and J.E. Board, 1997b. Growth dynamic factors controlling soybean yield stability across plant populations. Crop Sci., 37: 1520-1526.

8. Wells, R., 1991. Soybean growth response to plant density: Relationships among canopy photosynthesis, leaf area and light interceplistion. Crop Sci., 31: 755-761.

9. Loomis, R.S. and D.J. Connor, 1992. Community Concepts. In Crop Ecology: Productivity and Management in Agricultural Systems. Cambridge Univ. Press, Cambridge, UK., pp: 32-59.

10. Jiang, H. and D.B. Egli, 1993. Shade induced changes in flower and pod number and flower and fruit abscission in soybean. Agron. J., 85: 221-225. 